УДК 681.513 .8

\title{
COMPLEXATION OF CONTROL THEORY METHODS IN AUTOMATION SYSTEMS FOR TECHNOLOGICAL PLANTS. PART 1. COMMON TERMS
}

\author{
A. Ladaniuk, N. Lutska, V. Kyshenko, Ya. Smitiukh, D. Shumyhai \\ National University of Food Technologies
}

\begin{tabular}{|c|c|}
\hline Key words: & ABSTRACT \\
\hline $\begin{array}{l}\text { Complexation } \\
\text { Robustness } \\
\text { Coordination } \\
\text { Uncertainty } \\
\text { Emergent properties }\end{array}$ & \multirow{3}{*}{$\begin{array}{l}\text { The article discusses the possibility of synthesis of existing } \\
\text { methods and principles of control to get new more sophi- } \\
\text { sticated systems that would have emergent properties and } \\
\text { allow to increase the efficiency of complex technological } \\
\text { systems. The authors proposed to combine robust and opti- } \\
\text { mal control methods, robust and adaptive ones, coordination } \\
\text { and situational methods, etc. The obtained control systems, } \\
\text { which cannot be obtained via trivial use of both methods } \\
\text { chosen for complexation, provide quality and efficient con- } \\
\text { trol of complex plants for which the standard control system } \\
\text { cannot guarantee the required accuracy. }\end{array}$} \\
\hline $\begin{array}{l}\quad \text { Article history: } \\
\text { Received } 03.05 .2017 \\
\text { Received in revised form } \\
\text { 13.05.2017 } \\
\text { Accepted } 16.06 .2017\end{array}$ & \\
\hline $\begin{array}{l}\text { Corresponding author: } \\
\text { A. Ladaniuk } \\
\text { E-mail: } \\
\text { npnuht@ukr.net }\end{array}$ & \\
\hline
\end{tabular}

DOI: $10.24263 / 2225-2924-2017-23-4-3$

\section{КОМПЛЕКСУВАННЯ МЕТОДІВ ТЕОРІЇ КЕРУВАННЯ В СИСТЕМАХ АВТОМАТИЗАЦІї ТЕХНОЛОГІЧНИХ ОБ’ЄКТІВ. ЧАСТИНА 1. ЗАГАЛЬНІ ПОЛОЖЕННЯ}

\author{
А.П. Ладанюк, Н.М. Луцька, В.Д. Кишенько, Я.В. Смітюх, Д.А. Шумигай \\ Національний університет харчових технологій
}

У статті розглянуто можливості комплексного використання існуючих методів і принципів керування для отримання нових більш досконалих систем, які б мали властивості емерджентності та давали змогу підвищити ефективність функціонування складних технологічних комплексів. Запропоновано комплексування методів робастного й оптимального керування, робастного й адаптивного, ситуаційного та координаційного керування та інших методів. Новостворені системи керування завдяки своїм новим властивостям, які неможливо отримати при тривіальному використанні обох методів, обраних для комплексування, можуть забезпечувати якісне та ефективне керування складних об'єктів, для яких стандартні системи керування не можуть гарантувати необхіднӧ точності за умови енегро- та ресурсоефективності.

Ключові слова: комплексування, робастність, координація, невизначеність, емерджентність. 
Постановка проблеми. Сучасна теорія керування використовує ряд методів для підвищення ефективності керування складними об'єктами, серед яких важливе місце займають технологічні процеси, агрегати та комплекси 3 урахуванням їх суттєвих особливостей $[1 ; 2]$. Кожен із методів автоматизації має своє призначення та галузь застосування, а однією з важливих тенденцій, особливо в останні два-три десятиліття, стало об'єднання цих методів комплексування - для забезпечення високих техніко-економічних показників функціонування складних об'єктів, яке повинно відповідати поставленим цілям та мати науково-технічне обгрунтування, насамперед щодо використання коректних математичних засобів і можливостей програмного й технічного забезпечення в системах автоматизації. Комплексування базується на перевагах у досягненні цілей на основі системного підходу та ефекту емерджентності, який полягає в тому, що система має нові (емерджентні) властивості, яких не має жоден з іiі елементів (підсистем), але це не визначається простою сумою властивостей окремих частин, у тому числі використовуваних методів. Таким чином, коли мова йде про методи автоматизації, то їх відбір визначається системоутворювальним ефектом щодо сприяння досягненню мети при функціонуванні системи. Для визначення системоутворювальних факторів необхідно на основі аналізу функцій i цілей системи враховувати насамперед ряд характеристик та властивостей, які є інваріантними для будь-якої системи: цілісність, взаємозалежність, когерентність, стохастичність, цілеспрямованість, еволюціонізм, відкритість, тривалість неперервного функціонування.

Для систем автоматизації емерджентність проявляється за рахунок взаємодії підсистем (елементів) або використання нових методів, їх комплексування. Крім того, емерджентність забезпечує:

- значне нелінійне підсилення малопомітної раніше властивості;

- непередбачений поділ (біфуркації) будь-якої підсистеми;

- рекомбінацію зв'язків між елементами. Використання ієрархічних систем керування приводить до виражених системних ефектів, у тому числі емерджентності, але додавання до існуючої системи нових, більш високих рівнів ієрархії уповільнює зростання системних ефектів порівняно 3 нижніми рівнями. Разом $з$ тим, чим вищий ступінь ієрархічності системи керування, тим вона менше змінює рівень системності і тим більша живучість системи, що пояснюється наявністю системоутворювальних факторів на різних рівнях організації системи.

Мета дослідження: аналіз існуючих методів керування складними технологічними об'єктами $з$ урахуванням їх переваг, що можуть бути комплексовані, для одержання систем керування з новими якісними властивостями.

Виклад основних результатів дослідження. Комплексування методів автоматизації збігається за часом з розробкою та впровадженням інтегрованих систем керування різного призначення, що в 90-х роках минулого століття за рахунок розвитку комп'ютерних технологій і нових видів ЕОМ призвело до створення нових структур у рамках концепції комп'ютерноінтегрованого виробництва - CIM (Computer-integrated manufacturing) [3; 4]. Виробництва та технологічні комплекси неперервного типу характери- 
зуються значними матеріальними та енергетичними потоками, що породжує значні інформаційні масиви, які використовуються в системах автоматизації.

При цьому виробничий процес та основне технологічне обладнання $є$ інтегрованими, тобто однозначно взаємозв'язаними й узгодженими на значних інтервалах часу, але функціонують в умовах суттєвих збурень, що приводить до задач стабілізації з урахуванням вимог до якості готової продукції й необхідності використання ресурсо- та енергоефективних методів і алгоритмів керування. Водночас у системах керування є можливості для оптимізації технологічних режимів та координації функціонування підсистем.

Подальший розвиток автоматизації як визначального напрямку науковотехнічного прогресу безпосередньо пов'язаний з появою та розвитком MESсистем (Manufacturing Execution System), в яких реалізуються функції оптимізації виробництва 3 використанням задач аналізу інформації та координації підсистем на основі спеціалізованих програмних комплексів. Використання MES-систем як спеціального промислового софту дає змогу значно підвищити фондовіддачу технологічного обладнання та досягти високих техніко-економічних показників виробництва [5]. Для конкретних умов завжди виникає науково-технічна задача розробки необхідного математичного забезпечення та надаються унікальні можливості комплексування сучасних методів автоматизації в рамках MES-систем для конкретного виробництва, особливо за умов інтеграції з ERP (Enterprise Resource Planning System) - системою планування ресурсів підприємства.

Про необхідність комплексування методів автоматизації на основі системного підходу як використання нових можливостей при обгрунтованому поєднанні кращих сторін різних методів у 2000 р. писав відомий фахівець у галузі теорії автоматичного керування А.А. Красовський: «Криза ... полягає в тому, що адаптивність, оптимальність, точність, робастність, модульність, надійність, безпека розглядаються окремо один від одного, автономно ... Разом 3 тим адаптивність і робастність практично не можуть існувати без прогнозування, екстраполяції на обмеженому ковзному інтервалі. Адаптивність і робастність без точності й енергозбереження не потрібні, тому що сучасна техніка вимагає граничного використання ресурсів, якщо не в штатних, то в аварійних ситуаціях.

Оптимальне адаптивне та робастне регулювання багатовимірних багатозв 'язних об'єктів можливе лише при використанні функціоналів узагальненої роботи» [6].

Починаючи 3 40-х та 50-х років минулого століття і до цього часу велику увагу викликає можливість ефективної компенсації збурень у рамках положень теорії інваріантності. Нескінченні дискусії щодо можливості створення абсолютно інваріантних систем з нульовою похибкою:

$\Delta \mathrm{X} \equiv 0, \forall t \in t_{\text {рег }}$ ( $t_{\text {peг }}$ - час регулювання) приводять до різних висновків щодо фізичної реанімації таких систем. Наприклад, В.М. Кунцевич показав можливості комплексування методів робастності, адаптивності та інваріантності, але за реальних умов при параметричній невизначеності моделі об'єкта мова може йти лише про квазіінваріантність і лише для лінійних систем [7]. 
В той же час у ряді наукових праць в останні 10-15 років продовжуються публікуватись нові результати, наприклад, у [8] показано, що можна отримати умови досяжності інваріантності системи керування для енергетичних об’єктів, а можливості синтезу інваріантних систем на основі моделей у координатах стану використовують методи технології вкладення [9]. Такий підхід дає можливості одночасного забезпечення стійкості, інваріантності та оптимальності систем керування. Для задач керування різними об'єктами, насамперед багатовимірними та багатозв'язними, в ряді праць отримано результати умов вибіркової інваріантності, у тому числі інваріантності однієї координати об'єкта від (n-2) збурень або $(n-2)$ координат від одного збурення (n-порядок системи).

Достатньо відома постановка задачі щодо параметричної інваріантності, коли забезпечується незалежність вихідних змінних системи не лише від зовнішніх збурень, а й від зміни іiі параметрів (двократна інваріантність). Це дало змогу на одній основі розглядати питання керованості, інваріантності та чутливості. На відміну від основоположних понять щодо керованості (Р. Калмана), коли розглядається лише вектор керувальних дій для переведення системи у потрібний стан, у розгляд вводиться також вектор зовнішніх збурень, вектор зміни параметрів, а також початкові умови стану системи.

Часто виникала задача об'єднання можливостей інваріантного та оптимального керування, але це потребує використання спеціальних підходів. Аналізуючи цю проблему, автор статті пише: «... Це була втрачена можливість створення нового типу регулятора та систем керування. ... Цьому сприяла теорія оптимального керування, яка успішно розвивалась i, начебто, повинна була вказати кращі системи керування, але інваріантного керування вона виявити не змогла, оскільки таких, які пропонував Г.В. Щіпанов (автор теорії інваріантності - авт.) немає, а є квазіінваріантні. Це практично одне i теж, але серед квазіінваріантних немає оптимальних, i тому теорією оптимального керування вони не могли бути виявлені. ... Постановка задачі оптимізації повинна бути суттєво зміненою.

Особливістю квазіінваріантних систем керування $є$ також наявність великого коефіцієнта підсилення, оскільки малі значення похибки повинні привести до компенсації порівняно значного зовнішнього збурення» [10].

Нові можливості для комплексування методів автоматизації надають інтелектуальні системи, які стрімко розвиваються, розширюючи сфери застосування, про що може свідчити також використання квантових обчислень [11]. У цьому підході розглядаються задачі проектування робастних інтелектуальних систем керування в умовах непередбачуваних ситуацій функціонування системи. Комплексування у цьому разі полягає в тому, що використовується квантовий алгоритм керування самоорганізацією, зокрема для робастних баз знань. Якісні характеристики керування (стійкість, керованість, робастність) оцінюються за термодинамічним критерієм у вигляді мінімуму узагальненої ентропії. Квантовий алгоритм керування самоорганізацією використовується для суттєво нелінійного та глобально нестійкого об’єкта для розв'язання задачі векторної оптимізації на основі принципу декомпозиції баз знань. Ефективність застосування інтелектуальних систем 
керування визначається гарантованим досягненням мети керування на верхньому рівні та мінімальною витратою корисного ресурсу системи «об'єкт керування-регулятор» на нижньому (виконавчому) рівні ієрархічної системи автоматичного керування.

Поєднання робастних систем 3 іншими методами керування на сьогодні проявляється в двох аспектах: на основі теорії чутливості та використання $\mathrm{H}_{\infty}$-норми однієї 3 характеристик системи як критерію керування. Перший підхід базується на існуючих методах синтезу (нечіткі регулятори, нейронмережеві регулятори або алгоритми, адаптивні системи тощо), а для доведення їх робастності використовується теорія чутливості [12; 13]. Другий підхід має два напрямки — це робастний регулятор в системі з переключенням [14; 15] та в структурі системи керування [16], де поряд 3 робастним регулятором існують адаптивні або інтелектуальні блоки.

Одним із підходів збільшення ефективності функціонування складних ТК є синтез методів координації та методів ситуаційного керування. Необхідність вирішення задачі координації пояснюється тим, що при оцінці ефективності функціонування ТК саме взаємні зв'язки між підсистемами мають найбільш суттєве значення. Даний підхід може бути застосований до будьяких складних об'єктів, які мають складні нелінійні зв'язки. Для вирішення задачі координації необхідно провести аналіз досліджуваного об'єкта, виділити підсистеми та критерій оцінки ефективності, сформувати алгоритми координації та комплекс системи керування на основі виділених підсистем. При декомпозиції ТК на підсистеми виникає ієрархічна структура i, як результат, формується глобальна мета системи та частинні цілі підсистем. Розв'язанням задачі координації є визначення взаємодії підсистем, при яких керування, оптимальні за критеріями ефективності кожної 3 підсистем, $є$ також оптимальними за загальним критерієм для ТК в цілому [17]. Проте виробничі процеси відбуваються в умовах, що характеризуються певним діапазоном зміни параметрів процесів, вихід за які означає появу нештатної (аварійної) ситуації, пов'язаної з порушенням виробничого регламенту (всілякі порушення в ході технологічних процесів, вихід 3 ладу технологічного обладнання, збій електроживлення тощо) [17]. Поставлена задача розв'язується за рахунок того, що система автоматизації процесів координації підсистем ТК 3 використанням ситуаційного керування містить у своєму складі координатор, класифікатор, базу знань, розв'язувач, аналізатор. У режимі реального часу координатор розв'язує задачу координації за принципом прогнозування взаємодій, координатор в явному вигляді визначає момент часу та дії координації, що мінімізує ймовірність виникнення нештатних ситуацій, а якщо вже така ситуація виникла, то шукає ідентичні ситуації в базі знань, а за їх відсутності — переглядає вплив обраного ним рішення на кілька кроків вперед на основі описів об'єкта керування і процесів, що відбуваються в ньому. При вдалому прогнозі координатор приймає відповідне рішення з подальшим занесенням ситуації та виробленого керування до бази знань.

Для оцінки ефективності функціонування ТК використовується ряд економічних і техніко-економічних показників (собівартість продукції, прибуток, 
рентабельність, об'єм продукції, що випускається). Автоматизація процесу координації безпосередньо пов'язана зі зміною матеріальних потоків, технологічних режимів, зміною структури системи керування й об'єкта.

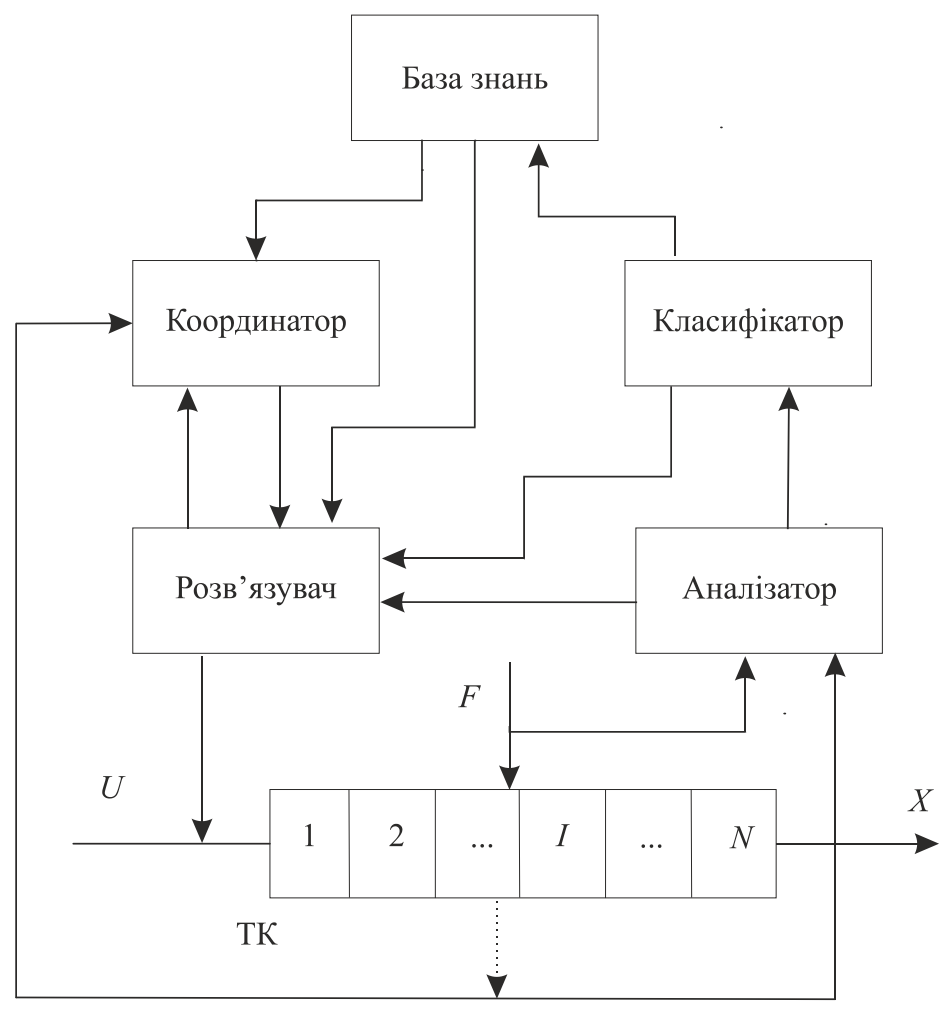

Рис. 1. Структура системи автоматизації процесів координації підсистем технологічного комплексу з використанням ситуаційного керування

Загальна оцінка функціонування технологічного комплексу із системою керування виконується на основі узагальненого економічного показника типу прибутку:

$$
\Pi=\int_{0}^{\text {Тзв }} \sum_{x=1}^{\mathrm{T}}\left(\mathrm{B}_{\mathrm{K}} Ц_{\mathrm{K}}-\sum_{\partial=1}^{\Pi} 3_{\mathrm{B}}\right) d(t),
$$

де $\mathrm{T}_{3 в}-$ звітний період часу; $\mathrm{B}_{\kappa}, Ц_{\kappa}-$ відповідно випуск та ціна $k$-го

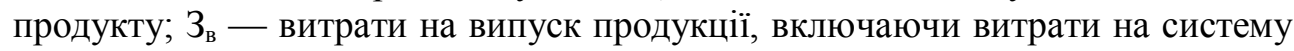
керування.

Інший підхід до ефективного керування складними ТК полягає в адаптивному керуванні технологічними об'єктами за прецедентами (рис. 1). Такий підхід грунтується на аналізі класу станів об'єкта та поєднує методи отримання даних, виведення на основі прецедентів і адаптивне керування в єдину самонавчальну систему, що дає змогу керувати об'єктами 3 недостатньо формалізованою поведінкою. 


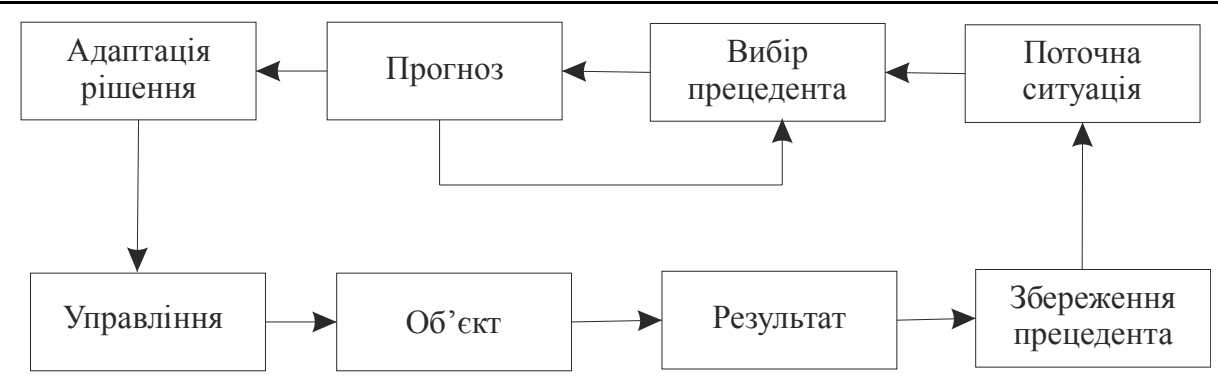

Рис. 2. Схема адаптивного керування за прецедентами

Цей підхід [18] передбачає виділення об’єктів, що слабко формалізуються, постановку задачі адаптивного керування на основі вибору прецедентів, об'єктивну оцінку результатів застосування в складі технологічних об'єктів. При недостатніх знаннях про об'єкт і середовище, в якому він функціонує, неможливо отримати точну модель поведінки об'єкта. Якщо відома лише апріорна інформація про стани об'єкта, керувальні впливи на нього і їx результати, це відповідає трьом складовим поняття «прецедент» - описом проблеми, застосованим рішенням і результатом його застосування $[19 ; 20]$. При керуванні за прецедентами [18; 21] стан об'єкта керування порівнюється 3 прецедентами із заздалегідь накопиченої бази даних, на основі обраної міри наближення вибирається один із схожих прецедентів. Керувальний вплив, який відповідає обраному прецеденту, використовується безпосередньо, або адаптується до поточного випадку, виходячи зі ступеня наближення до прецедента. Результат впливу також прогнозується за прецедентом, а підсумок впливу заноситься у відповідну базу даних для подальшого використання. Одночасно ставиться і завдання вибору міри наближення для визначення подібності стану керованого об'єкта до існуючих прецедентів, а задача ідентифікації стану об'єкта керування розв'язується за його спостережуваними (відомими) змінними та параметрами. Моделювання такого підходу до вирішення проблем, заснованого на досвіді минулих ситуацій, призвело до появи технології виведення, заснованого на прецедентах (Case-Based Reasoning, або CBR).

Комплексування як підхід також показує високі результати при використанні інтелектуальних методів і технологій при створені ефективних систем керування. Такі методи набувають широкого розповсюдження, одним 3 найбільш поширених $\epsilon$ метод створення гібридних мереж нейронечітких моделей. Концепція, покладена в основу такого підходу, в достатній мірі охоплює переваги результатів використання технології створення нейронних мереж $\mathrm{i}$ переваги представлення інформації та моделей знань, що будуються на основі нечітких множин і нечіткої логіки.

Апарат, який закладений в основу побудови цих мереж, має такі основні переваги [22; 23]:

1) можливість гнучкої інтерпретації нелінійних причинно-наслідкових зв'язків які згенеровані на основі нейронечіткої структури;

2) можливість донавчання розроблюваної структури.

Далеко неповний та достатньо короткий огляд проблеми комплексування методів сучасної теорії автоматичного керування дав можливість авторам виокремити такі класи систем автоматизації для технологічних об'єктів: 
- робастно-адаптивні;

- робастно-оптимальні;

- робастно-модальні;

- робастні із компенсацією запізнень;

- робастні із компенсацією збурень;

- ситуаційні системи координації;

- системи з адаптацією за прецедентами.

\section{Висновки}

1. У статті наводиться аналіз методів сучасної теорії керування та проблеми, які виникають при автоматизації складних технологічних об'єктів 3 властивостями нестаціонарності, невизначеності та одночасною появою нових вимог щодо ефективності та якості роботи цих систем.

2. Доведена ефективність поєднання ситуаційного керування та методів координації функціонування підсистем.

3. Показано, що метод комплексування надає широкі можливості для підвищення ефективності функціонування технологічними об'єктами 3 урахуванням ресурсо- та енергоефективних алгоритмів керування.

\section{Література}

1. Ладанюк А.П. Особенности задач робастного управления технологическими объектами. Часть 1. Технологические объекты и их математические модели / А.П. Ладанюк, Н.Н. Луцкая // Проблемы управления и информатики. — 2016. — № 5. - С. 16-23.

2. Луцька Н.М. Оптимальні та робастні системи керування технологічними об'єктами: [монографія] / Луцька Н.М., Ладанюк А.П. — Київ : Видавництво «Ліра-К», 2015. — 288 с.

3. Williams T.S. Интегрированный подход к управлению производственными процессами. / T.S.Williams // 10 World Congress on Automatic Control: Preprints JFAC. - 1987. P. 205-216.

4. Борзенко И.М. К вопросу об интеграции на автоматизированных предприятиях будущего / И.М.Борзенко, С.Г.Пиггот // Приборы и системы управления. — 1990. — № 1. — C. $4-8$.

5. Иикович Э.Л. Методы комплексной автоматизации производства предприятий технологических отраслей / Э.Л.Ицкович. — Москва : КРАСАНД, 2013. — 232 с.

6. Красовский А.А. Науковедение и состояние теории процессов управления / А.А. Красовский // Автоматика и телемеханика. — 2000. — № 4. - С. 3-19.

7. Кунцевич В.М. Квазиинвариантность, робастность и адаптация в системах управления / В.М.Кунцевич // Труды научного семинара «70 лет теории инвариантности». ЛКИ. 2008. - C. $61-91$.

8. Гайдук А.Р. Условия достижимости инвариантности систем управления энергетическими системами / А.Р.Гайдук // Автоматика и телемеханика. — 2006. - № 5. - С. 93-101.

9. Мисриханов М.Ш. Инвариантное управление многомерными системами / М.Ш. Мисриханов - Москва : Энергоатомиздат, 2005. - $236 \mathrm{c}$.

10. Неймарк Ю.И. Синтез и функциональные возможности квази-инвариантного управления / Ю.И. Неймарк // Автоматика и телемеханика. — 2008. — № 10. — С. 48-56.

11. Литвинцева Л.В. Интеллектуальные системы управления. І. Квантовые вычисления и алгоритмы самоорганизации / Л.В.Литвинцева, С.В.Ульянов // Известия РАН. Теория и системы управления. — 2009. — № 6. - С. 141-142.

12. Еремин Е.Л. Робастные алгоритмы нестационарных систем управления с явнонеявной эталонной моделью [Текст] / Е.Л. Еремин // Дифференциальные уравнения и процессы управления. 2001. - № 3. - С. 61-74. 
13. Цыкунов А.M. Робастное управление с компенсацией возмущений [Текст] / А.М. Цыкунов. - Москва : ФИЗМАТЛИТ, 2012. — 300 с.

14. Егупов Н.Д. Методы классической и современной теории автоматического управления: Учебник в 3-х т. Т. 3: Методы современной теории автоматического управления. / Н.Д. Егупов. - Москва : Изд-во МГТУ им. Н.Э. Баумана, 2000. - 748c.

15. Тимченко В.Л. Робастное управление буровым судном в режиме динамического позиционирования с учетом функциональных ограничений / В.Л. Тимченко, О.А. Ухин // Автоматизація технологічних і бізнес-процесів. - 2015. - Volume 7, Issue 3. - C. 10-17.

16. Morari M. Robust process control / M. Morari, E. Zafiriou. — Prentice Hall, 1989. — 488 p.

17. Ладанюк А.П. Система автоматизації процесів координації підсистем технологічного комплексу цукрового заводу з використанням ситуаційного керування / А.П. Ладанюк, Д.А. Шумигай, Р.О. Бойко // Патент України №73051. 10.09.2012, Бюл. № 17.

18. Карпов Л.Е. Адаптивное управление по прецедентам, основанное на классификации состояний управляемых объектов / Л.Е. Карпов, В.Н. Юдин // Труды Института системного программирования РАН. - 2007. - Т. 13, ч. 2. - С. 37-57.

19. Bundy A. Artificial Intelligence Techniques / Alan Bundy. - Springer Verlag, 1997. - $141 \mathrm{p}$.

20. Klaus-Dieter Althof. A Review of Industrial Case-Based Reasoning Tools / Klaus-Dieter Althof, Eric Auriol, Ralph Barlette, and Michel Manago. - AI Intelligence, 1995. — 159 p.

21. Карпов Л.Е. Методы добычи данных при построении локальной метрики в системах вывода по прецедентам / Л.Е. Карпов, В.Н. Юдин // Москва : Труды Института системного программирования РАН. - 2006. — № 18. - С. 32-38.

22. Ротштейн А.П. Интеллектуальные технологии идентификации: нечеткая логика, генетические алгоритмы, нейронные сети/ Ротштейн А.П. - Винница : УниверсумВинница, 1999. - 320 с.

23. Jang J.-S.R. ANFIS: Adaptive-Network-Based Fuzzy Inference System // IEEE Trans. Systems \& Cybernetics. - 1993. — Vol. 23. - P. 665 - 685 c. 